\title{
ROOF FALL CAVE, CANIA GORGE: SITE REPORT
}

\section{TONY EALES, CATHERINE WESTCOTT, IAN LILLEY, SEAN ULM, DEBORAH BRIAN AND CHRIS CLARKSON}

Aboriginal and Torres Strait Islander Studies Unit, University of Queensland, Brisbane, Queensland, 4072, Australia

\begin{abstract}
This site report presents a description of archaeological investigations undertaken at Roof Fall Cave, an occupied rockshelter and art site located at Cania Gorge, eastern Central Queensland. Field and laboratory methods are outlined and preliminary results are presented. Excavation yielded quantities of stone artefacts, bone and charcoal, along with some freshwater mussel shell and ochre with an occupational sequence spanning from up to $18,576 \mathrm{cal}$ BP to the historical period. Roof Fall Cave is currently the oldest dated site in Cania Gorge and possibly in the Central Queensland region.
\end{abstract}

\section{Introduction}

This report details preliminary results of two seasons of archaeological excavation conducted at Roof Fall Cave during September-October 1996 and July 1997 as part of the on-going Gooreng Gooreng Cultural Heritage Project (Figure 1; see Lilley and Ulm 1995, this volume). This paper presents a site description, preliminary rock art description and census and discussion of stratigraphy, chronology, field methods, laboratory procedures and preliminary results of analyses, including residue studies.

\section{Site Location and Description}

Roof Fall Cave is a large sandstone rockshelter adjacent to Cedar Creek, approximately $80 \mathrm{~m}$ south of the Big Foot Art Site (see Westcott 1997; Westcott, Lilley et al. this volume). Roof Fall Cave is one of a number of rockshelter sites excavated at the southern end of Cania Gorge (see Figure 3). The site is located in Cania Gorge National Park, approximately $20 \mathrm{~km}$ north-northwest of Monto and about $120 \mathrm{~km}$ from the coast (Latitude: 24 43'35"; Longitude: 150 59'32"; Easting: 296916; Northing: 7263846). The shelter faces east and is located on a steep slope, about $20 \mathrm{~m}$ above the creek flats below (Figures 3-4). The floor area is approximately $40 \mathrm{~m}^{2}$ inside the dripline and much of it is covered with large blocks of rapidlyweathering sandstone, fallen from the roof of the shelter (Figure 4). Scattered fragments of charcoal, freshwater mussel shell and stone artefacts, including large water-rounded cobbles exhibiting impact pitting, are present on the surface of the shelter. Paintings are visible on several sections of the walls, although many are deteriorating owing to exfoliation.

\section{Rock Art}

Rock art is present on the side and back walls of the rockshelter (Figure 2). The art assemblage consists of paintings only; there are no engravings or stencils. This style of execution is distinct from the predominantly stenciled art recorded to the west and southwest of Cania Gorge (e.g. Walsh 1984).

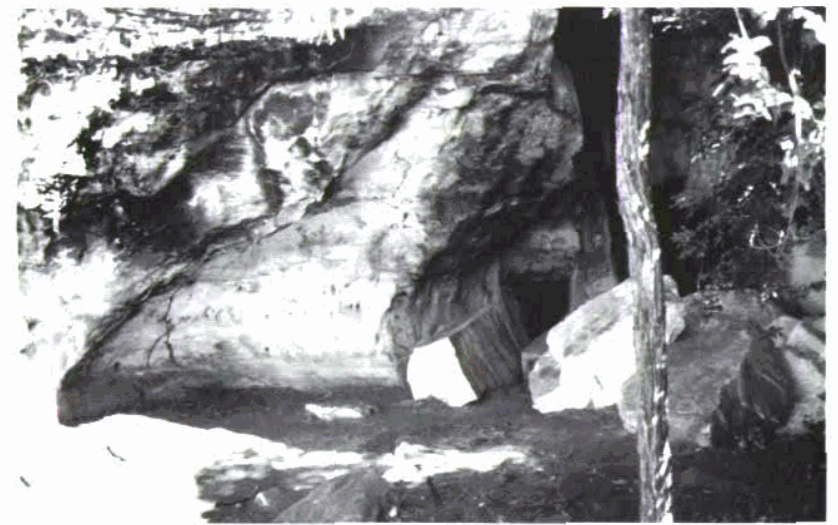

Figure 1. General view of Roof Fall Cave (Photograph: T. Eales).

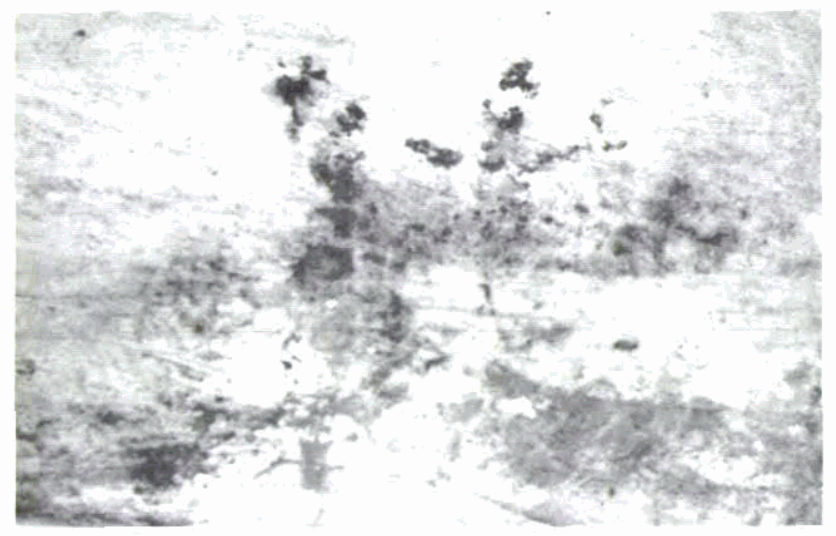

Figure 2. Zoomorphs on the rear wall immediately above Squares B and C (Photograph: D. Brian).

Table 1 provides a general description of the visible paintings in Roof Fall Cave. Many smears or stains of pigment were also noted that could not be assigned to a recognizable form. and these are omitted from Table 1. Heavy exfoliation of the sandstone surfaces from the walls of the shelter complicate delineation of the boundaries and form of many of the paintings. The entire assemblage is monochromatic, executed in solid colour with no outlines. 
Table 1. Preliminary description of rock art at Roof Fall Cave.

\begin{tabular}{|l|r|r|r|r|r|r|}
\hline & Anthropomorph & Zoomorph & Line & Trident & Unidentified & Total \\
\hline Red & $? 1$ & $? 1$ & 1 & & 2 & 5 \\
\hline Yellow & & & 1 & & & 1 \\
\hline Orange & & 1 & & & & 1 \\
\hline White & & & 1 & & & 1 \\
\hline Orange/Red & $? 2$ & $? 2$ & & & & 4 \\
\hline Pink/Red & & & 1 & 1 & & 2 \\
\hline Total & 3 & 4 & 4 & 1 & & 14 \\
\hline
\end{tabular}

One-third of the paintings are red and the remainder are executed in yellow, orange or white. Where colours are recorded as mixed, it is because one colour is superimposed over another, or one colour is weathering away to reveal another colour underneath. The colours are often faded and patchy. The origin of the white linear form recorded is uncertain as it may be either anthropogenic or the result of mineral precipitation. The anthropomorphs appear very faded and patchy. Three of the zoomorphs appear to be goannas but there is also some uncertainty with these figures because of the extent of exfoliation (Figure 2). The zoomorphs and non-figurative designs measure up to $95 \mathrm{~cm}$, although most are smaller than $65 \mathrm{~cm}$. The art assemblage is similar to that recorded at the nearby Big Foot Art Site (Westcott, Lilley et al. this volume).

\section{Excavation Aims and Methods}

Preliminary archaeological surveys of Cania Gorge confirmed that Roof Fall Cave was amongst the largest rockshelters with surface evidence of human occupation in the area. Test excavations at the site thus had the potential to provide an indication of the general occupational history and research potential of the area. The excavations conducted at Roof Fall Cave sought to assess basic questions concerning the nature, extent and antiquity of cultural remains and the age of the rock art.

In particular, attention was focused on the recovery of stone artefacts which had the potential to articulate the results from excavations in Cania Gorge to the wider region such as the Central Queensland Highlands (Mulvaney 1975; Mulvaney and Joyce 1965) to the west and southeast Queensland to the south.

During the 1996 season, a single $50 \mathrm{~cm} \times 50 \mathrm{~cm}$ test pit, Square A, located in the approximate centre of the shelter, was excavated to an average depth of $72 \mathrm{~cm}$. After receiving dates indicating considerable antiquity for occupation at the site, a further $50 \mathrm{~cm} \mathrm{x}$ $50 \mathrm{~cm}$ pit, Square $B$, and $50 \mathrm{~cm} \times 20 \mathrm{~cm}$ pit, Square C, were excavated in the 1997 season about a metre from Square A and adjacent to the back wall of the cave, below an art panel (Figure 4). Some difficultics were encountered in establishing a pit against the southwest wall of the rockshelter, owing to the curvature of the wall. Consequently, Square B was positioned $20 \mathrm{~cm}$ from the wall, leaving a small $(50 \mathrm{~cm}$ $x 20 \mathrm{~cm}$ ) area to the west of the square. This small excavation area was designated as Square C.

The three pits were excavated by trowel in small $(2-3 \mathrm{~cm})$ arbitrary excavation units (XUs) within stratigraphic units (SUs). SUs were delineated by changes in soil colour, composition or consistency. Elevations were recorded at the beginning and end of each excavation unit, using a local datum and string line level. Major finds and cultural material over $30 \mathrm{~mm}$ in maximum dimension encountered during excavation were generally plotted individually in situ in three dimensions and removed separately. All excavated sediments from each XU were weighed and dry-sieved on-site through a $3 \mathrm{~mm}$ sieve. All sieve residues were retained for laboratory processing. Samples (c.200g) of sediment passing through the $3 \mathrm{~mm}$ sieve were collected from each excavation unit.

Squares B and C were excavated to bedrock, with maximum depths of $60 \mathrm{~cm}$ and $31 \mathrm{~cm}$ respectively. Excavation of Square A yielded large quantities of stone artefacts, bone and charcoal as well as small amounts of freshwater mollusc shell and ochre. The excavated assemblage from Square B is awaiting analysis but initial observations suggest a similar overall assemblage composition to Square A. 


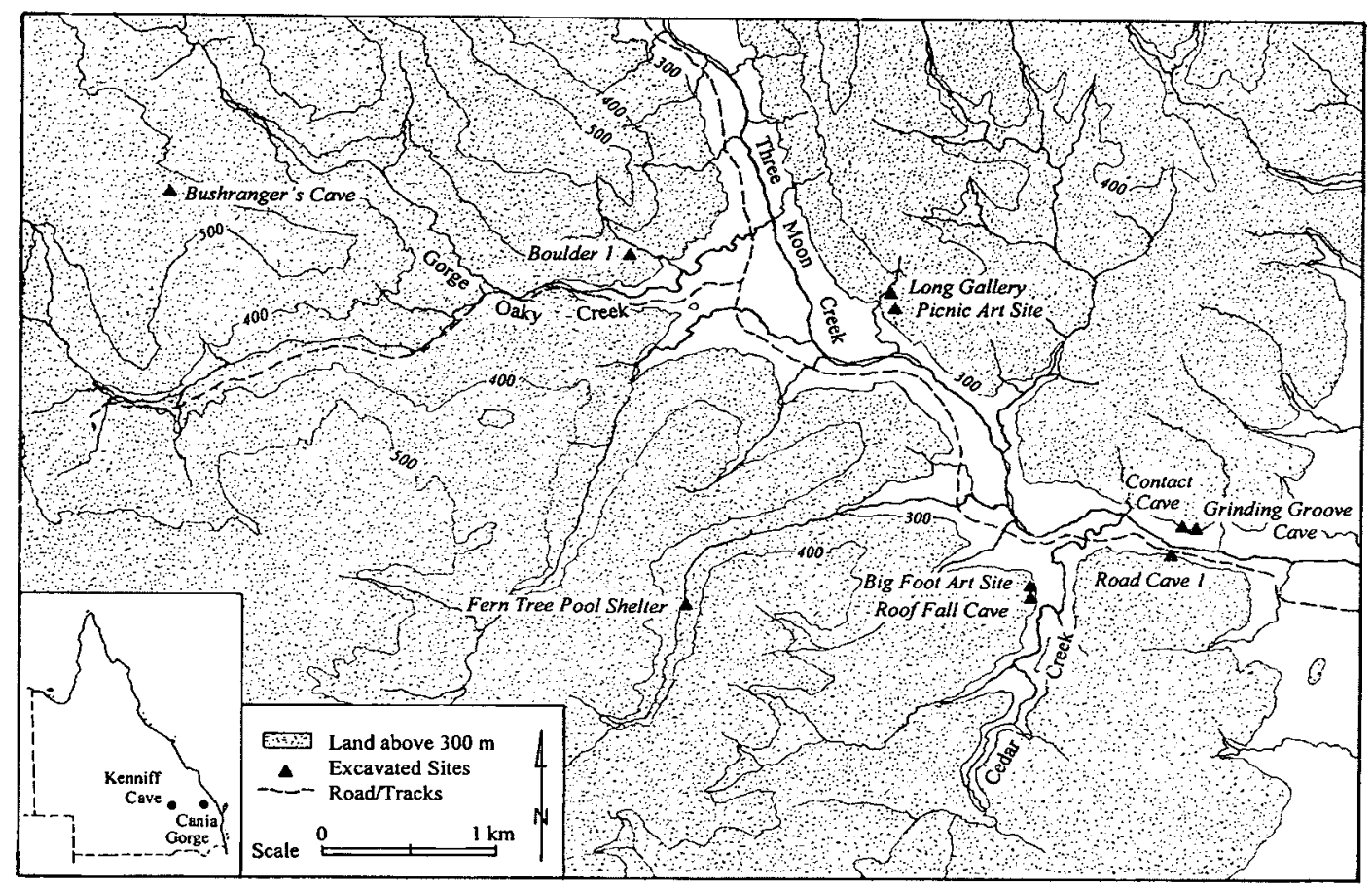

Figure 3. Southern Cania Gorge, showing excavated rockshelter sites.

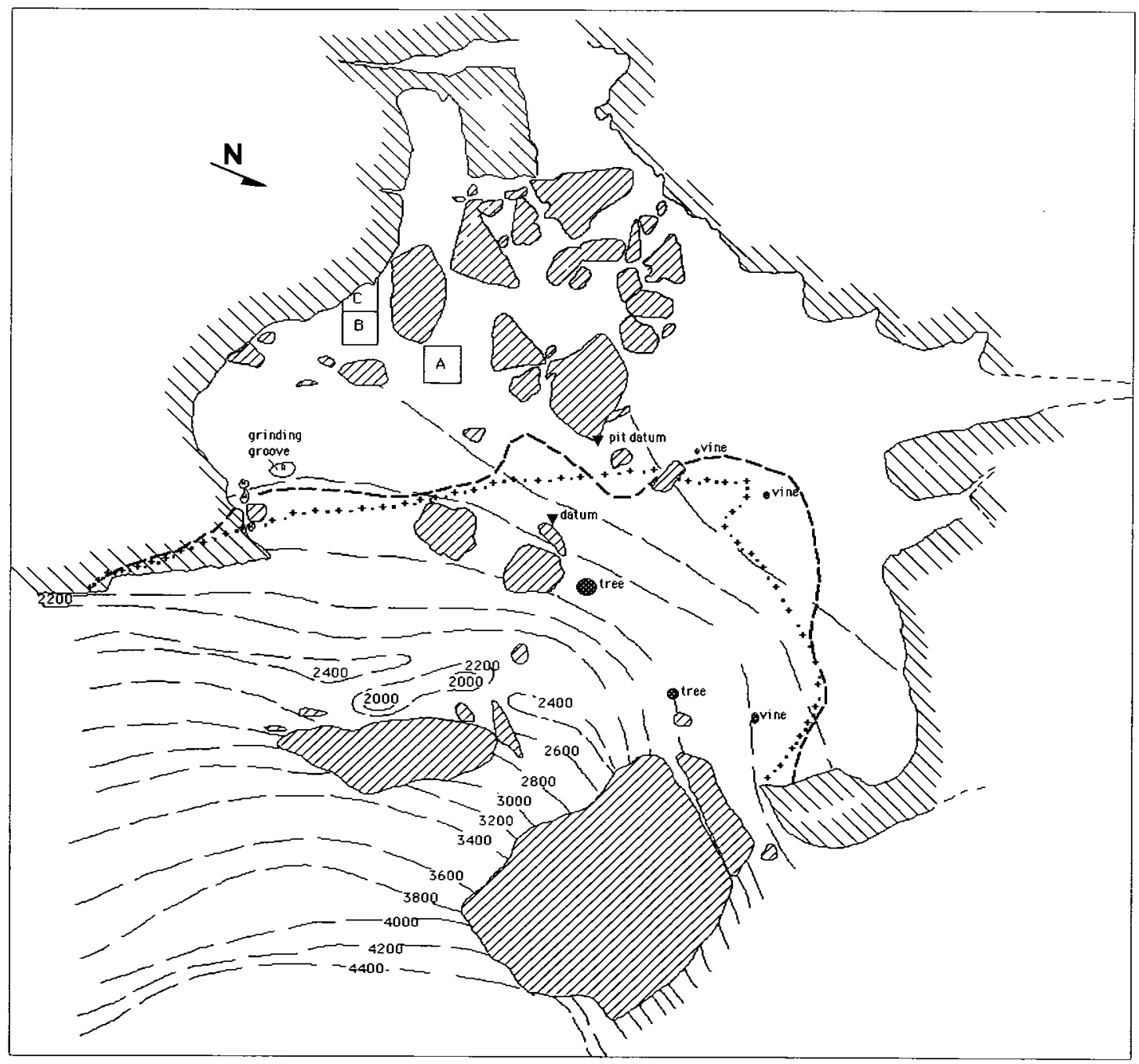

Figure 4. Site plan of Roof Fall Cave. 


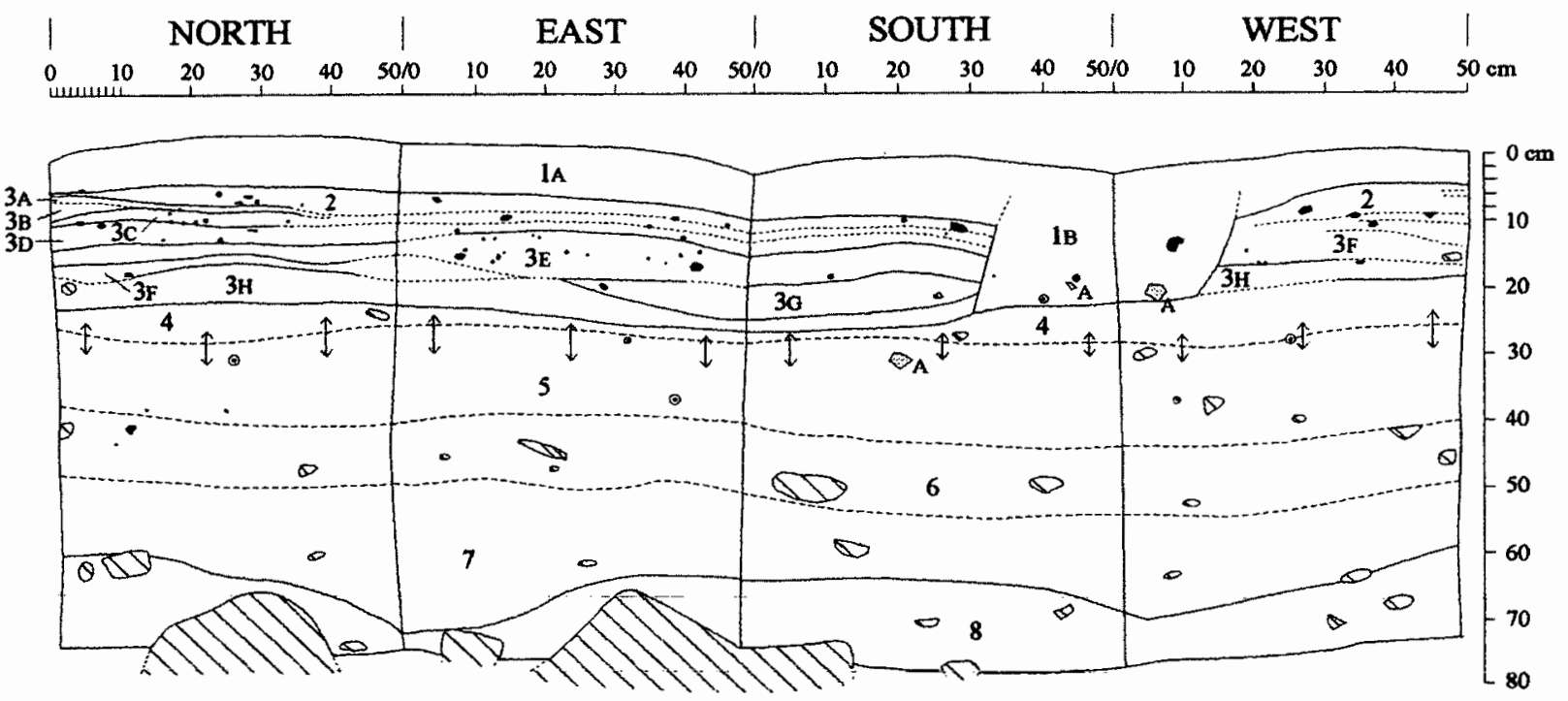

Figure 5. Section drawing of Square A, Roof Fall Cave.

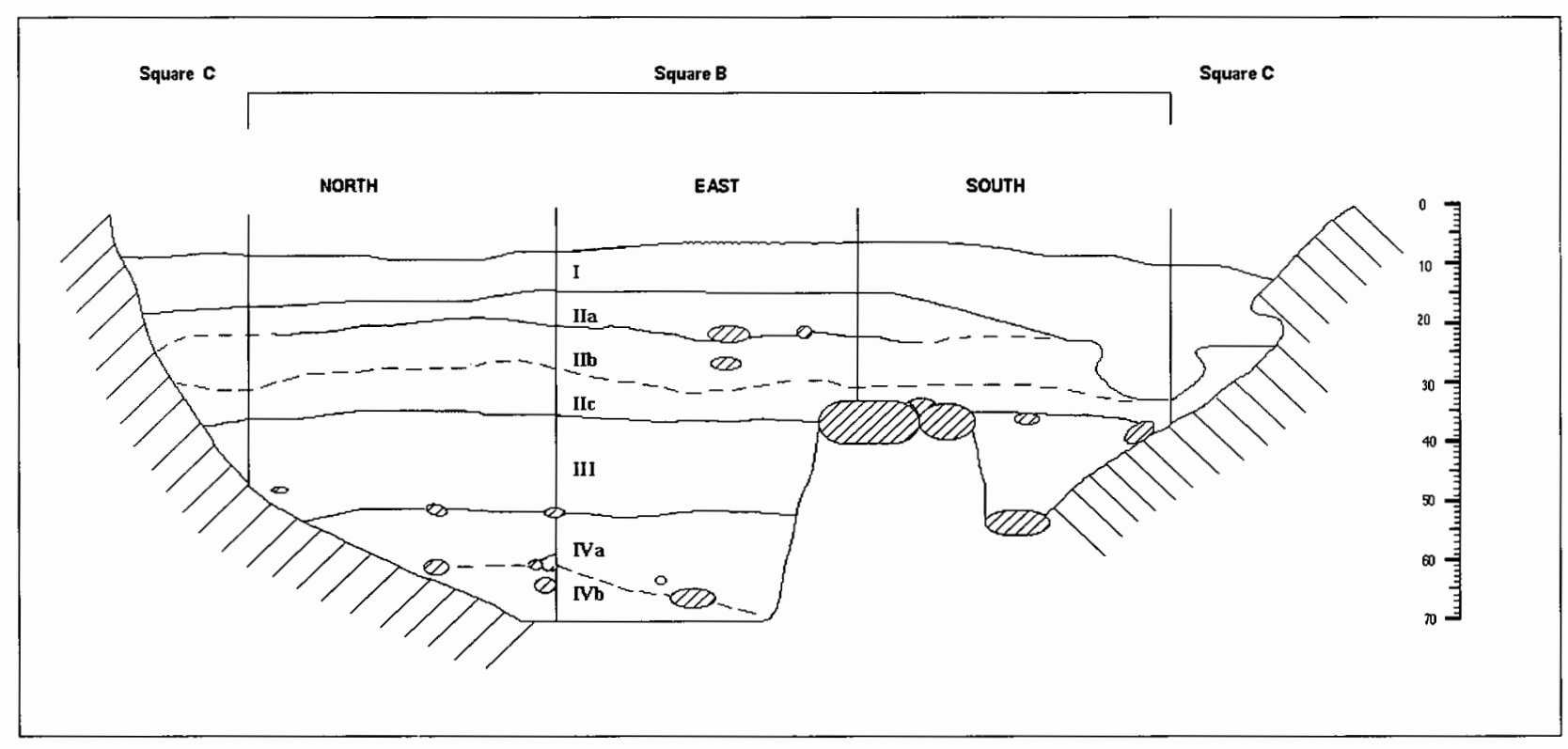

Figure 6. Section drawing of Squares B and C, Roof Fall Cave. 
Table 2. Stratigraphic units for Square A, Roof Fall Cave.

\begin{tabular}{|c|c|}
\hline SU & Description \\
\hline $1 \mathrm{a}$ & $\begin{array}{l}\text { Consists of non-compact ashy sediments incorporating large pieces of charcoal, twigs, grass, } \\
\text { roots and leaves. These sediments form the surface layer. Sediments are dry, with no apparent } \\
\text { structure. }\end{array}$ \\
\hline $\mathrm{lb}$ & $\begin{array}{l}\text { Consists of a stratigraphic disconformity. The origin of this disconformity is uncertain but } \\
\text { may result from the impact of a large block of roof fall within } 10 \mathrm{~cm} \text { of the corner of the } \\
\text { square. Structure: peds are approximately } 5 \mathrm{~cm} \text { maximum dimension and are prismatic. } \\
\text { Sediments are dry and grade in colour from light grey at the top to brown-grey at the bottom. } \\
\text { Sediments contain quantities of charcoal and ash; small rootlets are also common. Increasing } \\
\text { numbers of artefacts were noticed in this layer during excavation. }\end{array}$ \\
\hline 2 & $\begin{array}{l}\text { Sediments are dry and ashy and contain numerous large pieces of charcoal and fine rootlets. } \\
\text { This layer is light grey in colour. Peds range in size from 10-20mm and are blocky and sub- } \\
\text { angular. This layer is more compact than SU1, but still loose. }\end{array}$ \\
\hline $3 a$ & $\begin{array}{l}\text { Consists of a fine white ashy lens approximately } 1 \mathrm{~cm} \text { thick and most evident in the western } \\
\text { corner. Charcoal and calcined bone are abundant, as are fine rootlets. Sediments are dry. This } \\
\text { layer was too thin to ascertain the structure. }\end{array}$ \\
\hline $3 b$ & $\begin{array}{l}\text { This layer consists of grey, ashy sand. Charcoal, small rootlets and small pieces of sandstone } \\
(<2 \mathrm{~cm}) \text { are common. Sediments are dry and loose. This layer occurs in the western corner } \\
\text { only. Peds are } 25-30 \mathrm{~mm} \text { long and are blocky and angular. }\end{array}$ \\
\hline $3 c$ & $\begin{array}{l}\text { This layer is a light grey-brown, extremely ashy lens and contains quantities of charcoal, } \\
\text { rootlets and pieces of sandstone. This layer is more compact than SU2b. Peds are up to } 30 \mathrm{~mm} \\
\text { long and lenticular. }\end{array}$ \\
\hline $3 d$ & $\begin{array}{l}\text { Sediments are a darker grey-brown than SU3c. They contain large amounts of charcoal and } \\
\text { small rootlets. Sediments are dry and relatively compact. Peds are } 20-25 \mathrm{~mm} \text { long. }\end{array}$ \\
\hline $3 \mathrm{e}$ & $\begin{array}{l}\text { This layer is a thick, grey-white, mottled, ashy lens that is well defined in the northwest and } \\
\text { southwest sections only. Charcoal is common in small pieces. Sediments are quite compact } \\
\text { and dry. Peds are } 10-20 \mathrm{~mm} \text { long. }\end{array}$ \\
\hline $3 f$ & $\begin{array}{l}\text { This layer is a thin, ashy lens that grades from pieces of black charcoal in the west corner to } \\
\text { a fine, white, ashy lens in the southeast section, after which it is no longer clearly defined. } \\
\text { This layer is quite compact and dry and contains fine pieces of charcoal. It is best defined in } \\
\text { the southwest-northwest section. Peds range from } 25-35 \mathrm{~mm} \text {. }\end{array}$ \\
\hline $3 g$ & $\begin{array}{l}\text { These sediments occur only in the northeast and southeast sections. They consist of a dry, } \\
\text { hard, very compact, baked ashy layer, with fine pieces of charcoal and small rootlets. Peds are } \\
\text { approximately } 35 \mathrm{~mm} \text { long. }\end{array}$ \\
\hline $3 \mathrm{~h}$ & $\begin{array}{l}\text { Sediments are light-brown and very compact. They contain numerous small roots and some } \\
\text { larger ones. Sediments are dry and ashy, but slightly moister than previous layers. }\end{array}$ \\
\hline 4 & $\begin{array}{l}\text { This layer is light-brown in colour and contains many larger roots. The base of the layer is } \\
\text { transitional with that below it. }\end{array}$ \\
\hline 5 & $\begin{array}{l}\text { This layer consists of a homogenous, grey, ashy layer. Sediments are very compact. Peds are } \\
20-40 \mathrm{~mm} \text { in length and squarish to sub-angular. The base of the layer is transitional, grading } \\
\text { into the next stratigraphic unit over a } 7 \mathrm{~cm} \text { interval. }\end{array}$ \\
\hline 6 & $\begin{array}{l}\text { Sediments are very compact and dry. They contain small pieces of charcoal and fragments of } \\
\text { sandstone }(2-5 \mathrm{~cm}) \text {. The base of the layer is transitional, grading into the next stratigraphic } \\
\text { unit over a } 7 \mathrm{~cm} \text { interval. }\end{array}$ \\
\hline 7 & $\begin{array}{l}\text { Sediments are a very light, grey-brown, dry, extremely compact sand. There are numerous } \\
\text { small fragments of disintegrating sandstone }(20-50 \mathrm{~mm}) \text {. Peds are approximately } 50 \mathrm{~mm} \text { long. }\end{array}$ \\
\hline 8 & $\begin{array}{l}\text { Sediments consist of yellow sand and numerous large pieces of disintegrating sandstone. The } \\
\text { base of this layer was not reached but the excavated deposit is culturally sterile. }\end{array}$ \\
\hline
\end{tabular}


Table 3. Stratigraphic units for Square B, Roof Fall Cave.

\begin{tabular}{|c|l|}
\hline SU & \multicolumn{1}{|c|}{ Description } \\
\hline 1 & $\begin{array}{l}\text { The surface consists of a fine, loose, light grey, ashy deposit, containing leaf litter and some } \\
\text { coarser particles of sandstone. Large quantities of charcoal, some calcined bone and several } \\
\text { stone artefacts were found in this layer. }\end{array}$ \\
\hline $2 \mathrm{a}$ & $\begin{array}{l}\text { This is a slightly darker, more compact layer, which is also more brown in colour than SUI. } \\
\text { A fine matrix with stone artefacts, some charcoal and bone. }\end{array}$ \\
\hline $2 \mathrm{~b}$ & $\begin{array}{l}\text { The deposits form a slightly coarser-grained dark grey-black layer containing cultural } \\
\text { materials. The colour/texture difference may relate to a higher charcoal content. }\end{array}$ \\
\hline $2 \mathrm{c}$ & $\begin{array}{l}\text { Sediments are very similar to SU2a. Finer and lighter in colour than SU2b, but darker and } \\
\text { slightly more brown in colour than the rest of the deposit. This layer contains abundant } \\
\text { cultural material. }\end{array}$ \\
\hline 3 & $\begin{array}{l}\text { This layer is clearly differentiated from SU2. A lighter grey-brown sediment, slightly coarser } \\
\text { and less compact than those above. It appears to get progressively lighter in colour and } \\
\text { coarser and less compact with depth, although the stratigraphic discontinuity between SU3 } \\
\text { and } 4 \text { is distinct. It contains less cultural material than the layers above. }\end{array}$ \\
\hline $4 a$ & $\begin{array}{l}\text { A light-brown sandy layer, coarser and looser than the upper deposits. Contains small } \\
\text { fragments of charcoal and only a few stone artefacts. }\end{array}$ \\
\hline $4 b$ & $\begin{array}{l}\text { Sediments are lighter and more yellow-brown in colour than SU4a. They contain greater } \\
\text { quantities of sandstone rubble and are generally coarser and sandier than the units above. No } \\
\text { cultural material was observed during excavation of this unit. }\end{array}$ \\
\hline
\end{tabular}

\section{Stratigraphy}

\section{Square A}

Square A revealed a complex stratigraphy, with 16 separate units and sub-units identified (Figure 5). Some of the stratigraphic breaks were clearly delineated, while others were more difficult to define owing to grading of the deposit. SU3a-h consisted of many ashy lenses, some visible only in section. Sediments were generally loosely consolidated in the upper part of the deposit, becoming more consolidated in the lower deposits. No cultural material was recovered from the basal units of the deposit (SU8). Bedrock was not reached. Table 2 gives a detailed description of the stratigraphic units.

After the completion of excavation XUs were allocated to SUs on the basis of colour, degree of consolidation and composition of sediments, relative stratigraphic complexity and relative depths. The XUs comprising each SU are shown in Table 4.

\section{Squares $B$ and $C$}

Seven stratigraphic units were identified in the sections of Square B (Figure 6). Sediments were powdery in the upper layers of the excavation. The sediments in SUs $2 \mathrm{a}, 2 \mathrm{~b}$ and $2 \mathrm{c}$ were similar and the changes between them gradational. It is possible that these units represent minor variations within a single stratigraphic unit. The two lower SUs (4a and 4b) were sandier than the other units and contained little cultural material. The stratigraphic units are described in Table 3.

Table 4. Relationship of stratigraphic units to excavation units, Square $A$.

\begin{tabular}{|l|l|}
\hline \multicolumn{1}{|c|}{$\mathbf{S U}$} & \multicolumn{1}{|c|}{$\mathbf{X U}$} \\
\hline $1 \mathrm{a}$ & $1,2,3$ \\
\hline $1 \mathrm{~b}$ & $7 \mathrm{a}, 10 \mathrm{~b}$ \\
\hline 2 & 4 \\
\hline $3 \mathrm{a}-3 \mathrm{~h}$ & $5,6,7,8,9,1010 \mathrm{a}, 11,1 \mathrm{la}, 11 \mathrm{~b}, 12$ \\
\hline 4 & $13,14,15,16,17$ \\
\hline 5 & $18,19,20,21,22,23,24,25,26$ \\
\hline 6 & $27,28,29,30,31$ \\
\hline 7 & $32,33,34,35,36$ \\
\hline 8 & 37,38 \\
\hline
\end{tabular}


Table 5. Radiocarbon dates, Square A.

\begin{tabular}{|c|c|c|l|l|l|l|l|}
\hline Square & XU & $\begin{array}{c}\text { Depth } \\
(\mathbf{c m})\end{array}$ & Lab. No. & Sample & $\begin{array}{c}\text { Weight } \\
(\mathbf{g})\end{array}$ & \multicolumn{1}{|c|}{${ }^{14}$ C Age } & \multicolumn{1}{|c|}{ Calibrated Age/s } \\
\hline A & 6 & 11.5 & Wk-5596 & charcoal & 1.6 & Modern & Modern \\
\hline A & 10 & 15.0 & Wk-5597 & charcoal & 2.7 & $610 \pm 80$ & $665(547) 485$ \\
\hline A & 12 & 18.0 & Wk-5598 & charcoal & 2.6 & $710 \pm 90$ & $733(650) 516$ \\
\hline A & 20 & 29.0 & Wk-5599 & charcoal & 1.5 & $3770 \pm 150$ & $4513(4084,4020,4012) 3649$ \\
\hline A & 27 & 45.0 & Wk-5600 & charcoal & 2.5 & $7010 \pm 110$ & $7947(7729) 7547$ \\
\hline A & 31 & 55.0 & Wk-6218 & charcoal & 1.4 & $7690 \pm 210$ & $8984(8405) 7968$ \\
\hline A & 36 & 71.5 & Wk-5216 & charcoal & 1.3 & $15720 \pm 380$ & $19387(18576) 17814$ \\
\hline
\end{tabular}

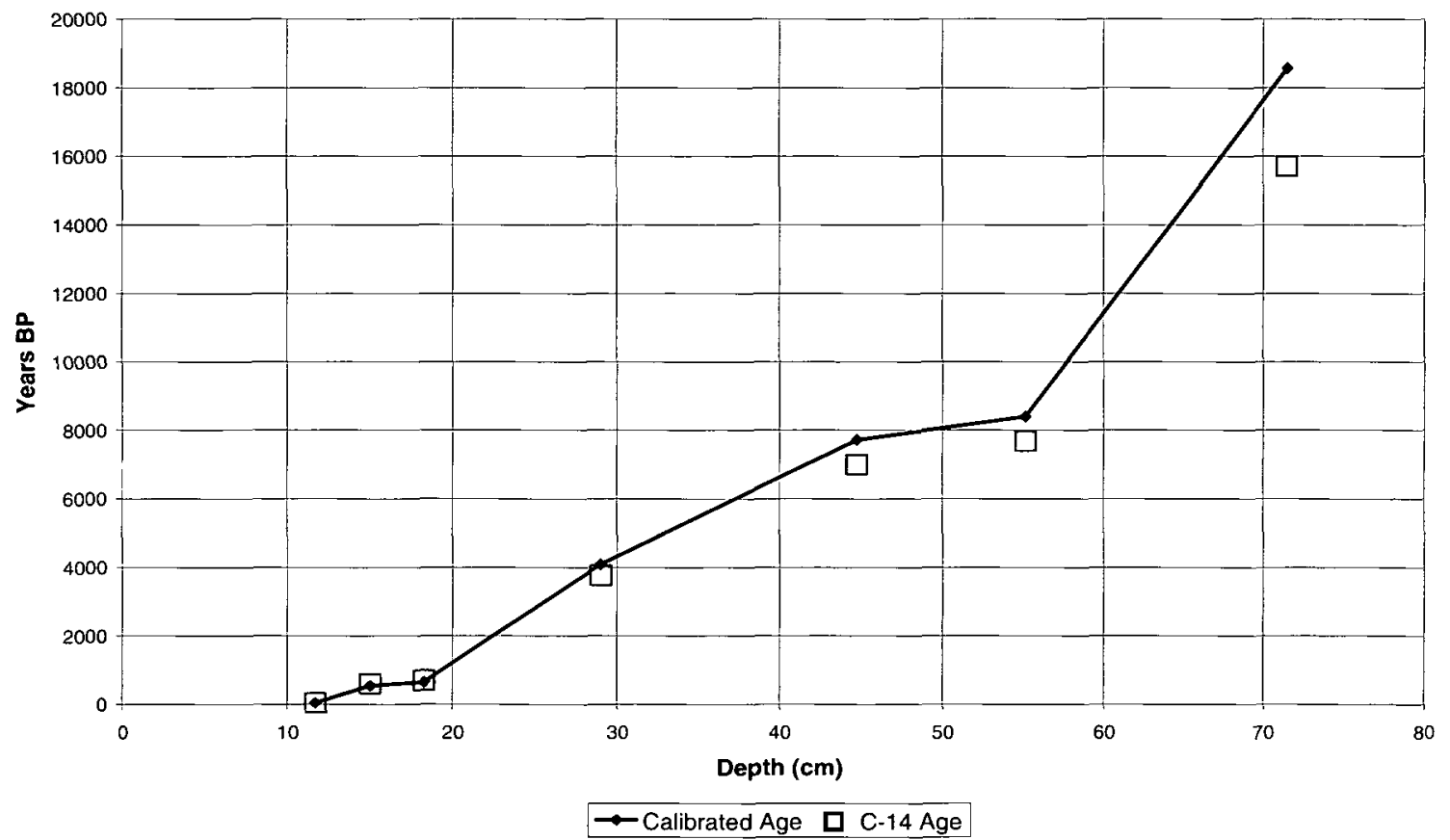

Figure 7. Age-depth plot of radiocarbon dates, Square A.

\section{Chronology}

Seven radiocarbon dates have been obtained from charcoal samples from Square A (Table 5). No samples from Squares B or C have yet been dated. Conventional ${ }^{14} \mathrm{C}$ ages are corrected for ${ }^{13} \mathrm{C} /{ }^{12} \mathrm{C}$ fractionation and were calibrated using the CALIB (Version 3.0.3c) computer program (Stuiver and Reimer 1993), using the bi-decal atmospheric calibration curve based on the datasets of Bard et al. (1993), Linick et al. (1986), Pearson et al. (1993), Pearson and Stuiver (1993), Stuiver and Pearson (1993) with no laboratory error multiplier. Forty years were subtracted before calibration to correct for ${ }^{14} \mathrm{C}$ variations between northern and southern hemispheres. The calibrated ages reported span the $2 \sigma$ calibrated age-range (Eales 1998; Lilley et al. 1998:30).
The seven radiocarbon dates and their associated sample depths were used to plot the age-depth relationship (Figure 7). The central tendencies of the radiocarbon ages were used, as were the mid-points of the calibrated ages. The resulting graph shows significant variation in deposition rates during the formation of the site. The most rapid periods of sediment deposition occurred between c. 8400 to 7800 cal BP and during the last 600 years. The slowest deposition rate occurs between c. 18,500 to $8500 \mathrm{cal}$ $\mathrm{BP}$. These variations in sedimentation rates contrast with the relatively consistent linear relationship between age and depth obtained from Big Foot Art Site (see Westcott, Lilley et al. this volume). These apparent differences may simply be the result of greater resolution owing to the larger number of dates available for Roof Fall Cave. 
The earliest date of $18,576 \mathrm{cal}$ BP was obtained from XU36 at a depth of $69-74 \mathrm{~cm}$, although the cultural associations of this determination remain to be confirmed by further excavation. On the basis of a detailed analysis of the lithic assemblage from Square A, Eales (1998) suggested that unambiguous stone artefacts are only represented from XU31, dating to 8,405 cal BP. If occupation occurred in the 10,000 years prior to this time, deposition rates were extremely low compared with later periods, suggesting only ephemeral occupation. The 'modern' radiocarbon determination obtained from a depth of $11.5 \mathrm{~cm}$ is probably related to post-depositional disturbance of the upper part of the deposit which has been attributed to recent cattle activity.

\section{Laboratory Procedures}

Cultural remains were found in varying densities up to approximately $70 \mathrm{~cm}$ below ground surface. Details of excavated remains from Square $A$ are presented in Appendix $A$. Although Squares $B$ and $C$ have not yet been analysed, field observation suggests a similar gross assemblage composition and structure to that revealed in Square A.

The material from Square A was sorted into the following components: artefactual stone, nonartefactual stone, charcoal, bone, organic material, insect remains, shell, ochre, earth nodules and unknown. A residue analysis of a sample of the stone artefacts from Square A has recently been completed (Eales 1998) and a faunal analysis of remains from Square A is currently being undertaken. The results reported below are based on preliminary data and provide a general description of the excavated deposit and a framework for continuing specialised analyses. Given the preliminary nature of the analysis, results are considered in terms of proportions of material per excavation unit.

\section{Results of Analysis}

Analysis of deposition rates for the different materials recovered were conducted in order to determine gross trends in deposition over time. Deposition rates for artefactual stone, charcoal, bone and shell were calculated as grams of material per kilogram of excavated deposit (Figure 8). In addition, the number of stone artefacts per kilogram of deposit was calculated for each $\mathrm{XU}$ and graphed against the weight of stone artefacts per kilogram of excavated deposit in order to assess fluctuations in the size of artefacts through time (Figure 9). The calculations were made on flaked stone artefacts only, which excluded one large pitted cobble in XU21.

XUs rather than SUs were selected for the purposes of preliminary analysis as XUs are small arbitrary units of a similar size that enable a more detailed overview of the structure of the deposit. Using XUs, the beginnings and ends of peaks or troughs in discard rates could be more accurately determined thus increasing the our ability to assign a chronological range to perceived changes in discard rates. Certain XUs proved to be problematic in this respect owing to the fact that certain stratigraphic features were excavated as separate XUs. XU10a, for example, was a small feature containing about $100 \mathrm{~g}$ of deposit yet contained 11 large artefacts. Such a feature would artificially skew any graph using this as single XU. To avoid this problem some XUs were combined according to depth. All XUs with the same numeric designation but different alphabetic designations are units from the same depth yet excavated separately according to perceived differences in the composition of the matrix. For example XU7a and XU10b represent the sediments of SU1b.(Figure 5). For the purposes of analysis weights and numbers of excavated materials from XUs with the same numeric designatiōn were combined.

The most obvious trend shown in Figure 8 is the high representation of charcoal, relative to other types of material in XUs 1-9, which represents the period between c. 550 cal BP and the present. After this time, stone artefacts and bone predominate with a peak between XU13 and XU16. High amounts of charcoal in the upper levels may be explained by changes in the use of the available floor space in the shelter after the roof fall event effectively made almost $80 \%$ of the floor space unavailable for hearths. The result would be a concentration of hearths in areas still available. As the later deposits represent a radically different spatial use of the shelter and associated changes in the material deposited, deposits dating after $600 \mathrm{cal}$ BP could not be compared meaningfully with those laid down prior to this date. The other major trend shown in Figure 8 is the increase in deposition rates of all material types, save charcoal, in the period after c. 4,000 cal BP. Prior to this date the graph reveals a very low but gradually increasing use of the shelter particularly after 7,700 cal BP (XU27).

The stone artefact data in Figure 9 show a trend towards the representation of relatively small artefacts throughout the deposit. Anomalies to this pattern occur in XU10, XU16 and XU26 corresponding to the occurrence of a number of larger artefacts in those XUs. The apparent lack of variation in artefact size seems to match the results of the technological analysis conducted on the assemblage from Big Foot Art Site (see Westcott 1997; Westcott, Lilley et al. this volume). The increase in artefact deposition after 4,000 cal BP at Roof Fall Cave also mirrors that of Big Foot Art Site and therefore indicates a continuity in aspects of site use between the two shelters. 


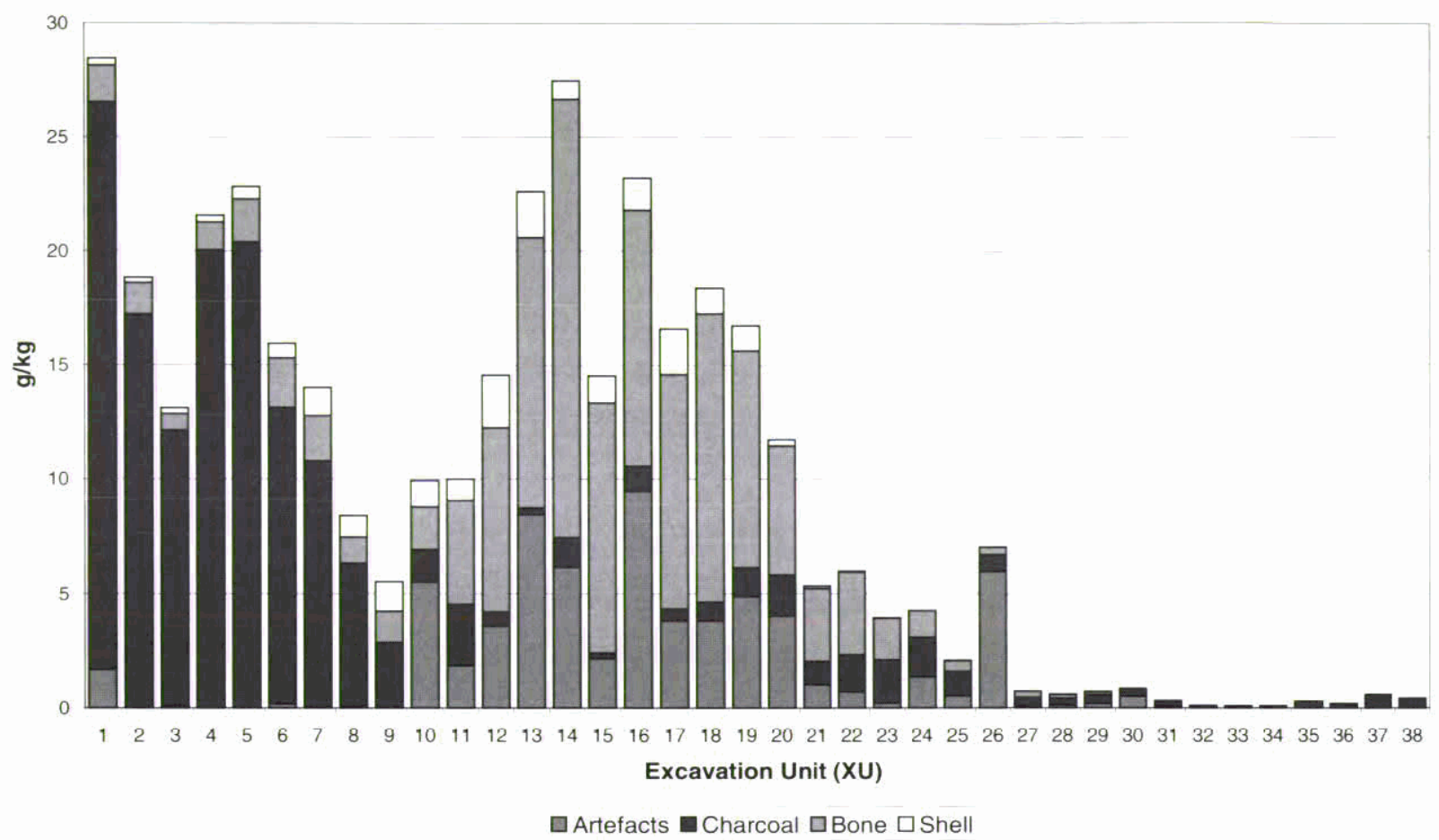

Figure 8. Distribution of excavated materials per XU, Square A, expressed as grams per kilogram of deposit.

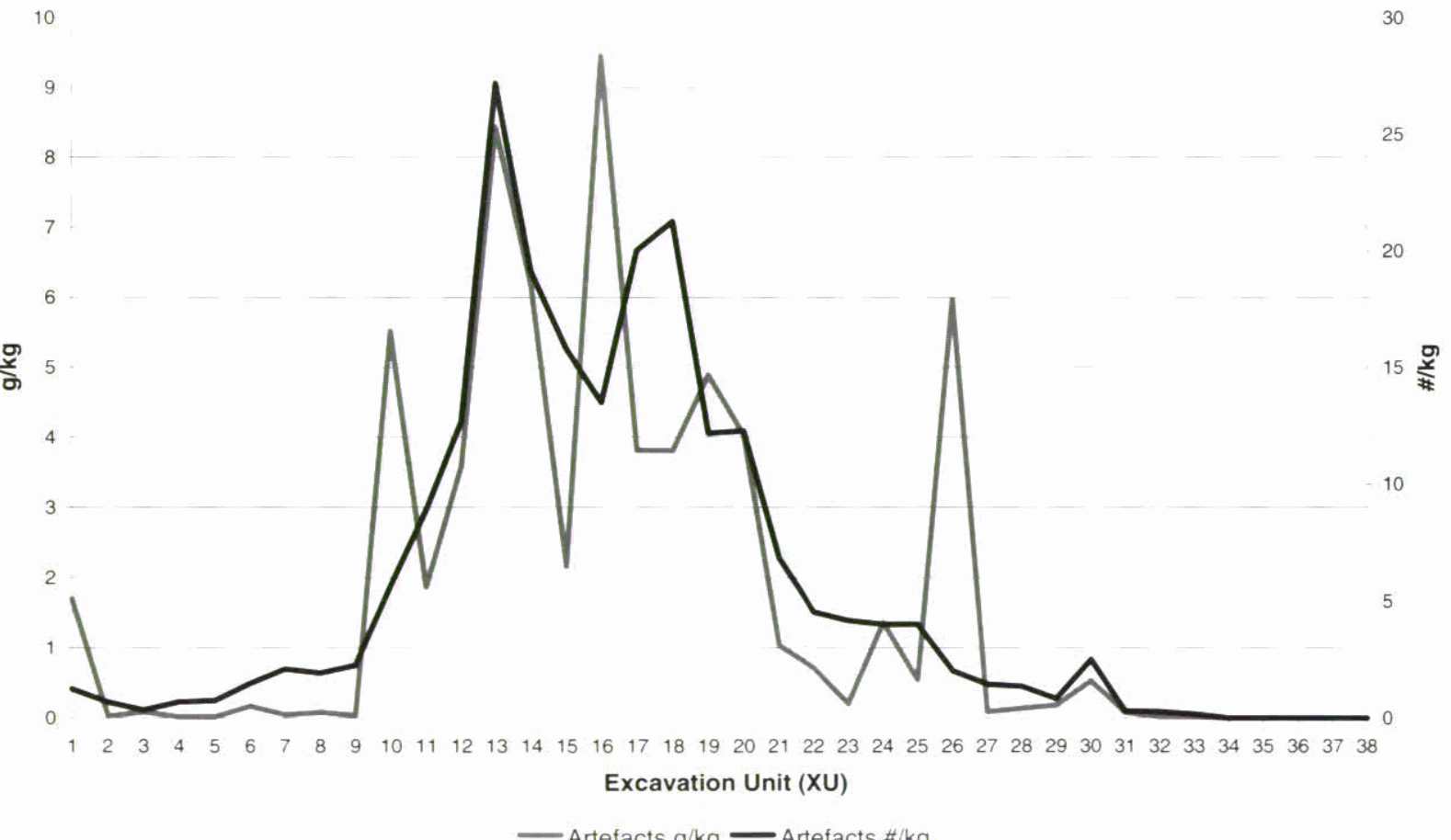

Figure 9. Distribution of artefactual stone per $\mathbf{X U}$, Square A. (The left-hand $\mathbf{y}$-axis shows grams per kilogram of deposit and the right-hand $y$ axis expresses the number of stone artefacts per kilogram of deposit). 


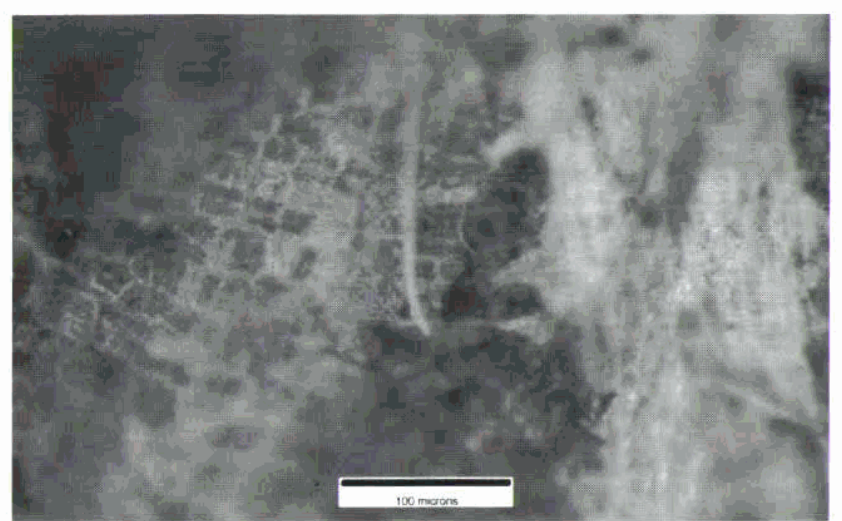

Figure 10. Woody plant tissue on artefact surface at $100 \mathrm{X}$ magnification.

\section{Residue Analysis}

Residue analysis is a technique used to identify the materials on which a stone tool has been used by the analysis of the traces of such materials bound to the stone surface. This technique has been in use since the 1970s when Briuer (1976) first noted the presence of preserved organic material on stone tools from dry caves in North America. The technique was further developed by Shafer and Holloway (1979) who saw the technique as a means of determining stone tool function. Further advances were made by Loy (1983) who discovered preserved traces of blood on stone tools from Turkey.

The purpose of conducting residue analysis on the stone assemblage from Roof Fall Cave was to address questions relating to the use of the stone artefacts and, by implication, the use of the cave. Residue analysis has the potential to indicate on what materials stone tools were used and by inference associate tasks with tools (Loy 1993). If one can identify the tasks performed with specific tools from an assemblage assumptions can be made about what tasks were performed at the site in the past. The successful execution of residue analysis requires the accumulation and integration of evidence from a variety of sources and techniques. These include (but are not confined to) incident, transmitted, high- and low-power microscopy, collection and comparison with reference collections, experimental replication, use-wear analysis and chemical analysis of residues (Loy 1994, 1997).

For the purposes of the analysis, only stone artefacts from Square A were considered. The assemblage was size-classed and only those artefacts that were $15 \mathrm{~mm}$ and above in maximum dimension were analysed. This arbitrary size limit was selected as multiple sampling of residues from the artefact surfaces is difficult on small artefacts.

Each artefact was examined with a low-power incident-light microscope and an incident-light metallurgic microscope using normal and cross-

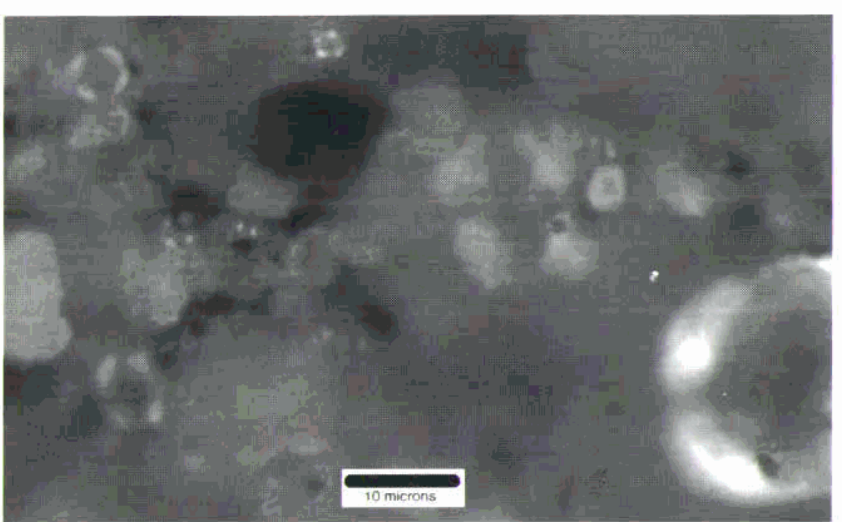

Figure 11. Starch-grains at 500X magnification under cross-polarised light.

polarised light. In this way, residues were located and provisionally identified. Further tests were conducted on specific residues. Extractions of residues were taken and examined under a transmitted light microscope to facilitate detailed description of residue elements. Extractions were also taken from each artefact to test chemically for the presence of preserved blood proteins.

\section{Results of Analysis}

Residues discovered on artefact surfaces were starch grains and other idioblasts and phytoliths, saps and resins, woody and bark plant tissue, macerated plant tissue and cellulose, and plant fibres. No traces of animal-related residues such as blood proteins were found. The starch grains found were primarily very small undiagnostic grains and could well be environmental contaminants rather than associated with use. Similarly idioblasts such as raphides and phytoliths occurred in amounts too small on any given artefact to be associated explicitly with artefact use.

In contrast, most of the plant tissues, fibres and resins could be associated with use owing to the large quantities observed, their locations and orientations on the artefact surfaces, associated use-wear and patterning, and their adherence to the artefact surface. Many of the tissues were found rammed into cracks and disconformities in the artefact surfaces or adhering to the surface in resinous substances.

The vast majority of plant tissues were macerated and many collapsed and twisted cell walls were noted. Fibres showed orientations consistent with artefacts being pushed into or dragged across fresh, fibrous plant-matter. Bark cells were found stacked up upon one another. Resins showed smearing and striations on the surface. The accumulation of such evidence is highly indicative of use-related residues rather than environmental or post-excavation contamination.

A small reference collection of plant samples was 
collected from the gorge. Parts of plants ethnographically recorded as being of economic importance to Aboriginal people were targeted, such as barks, resins, seeds, fibrous reeds, roots and tubers. These samples were examined microscopically and experimentally processed using replicated stone artefacts. These experimental artefacts were examined using the same protocols as for archaeological artefacts. The results of these tests were inconclusive, but a tentative match between reference samples of Xanthorrhoea johnsonii resins and fibres and many of the residues on the archaeological artefacts can be made. In addition, there are many similarities between the woody/bark tissue residues and collected eucalypt bark tissue.

\section{Analysis of Results}

After identifying and documenting the residues, attempts were made to associate the occurrence of certain residue elements within wider systems of analysis and interpretation. Variations in the distribution of residue elements through time, between raw materials and in association with each other, were analysed.

For the purposes of analysis, the residue elements were grouped into gross categories. These categories were:

a. Starch-grains greater than $10 \mu \mathrm{m}$ in maximum dimension. This included both compound grains and partially-gelatinized grains;

b. Resins. This category included all plant exudates;

c. Woody and bark tissues. All regularly structured plant tissue and cellulose with thickened cellwalls;

d. Fibres. Interlaced or single fibres of plant origin;

e. Other plant tissue or cellulose. This category included all plant tissue that was unstructured, macerated or from parts of plants other than those listed above; and,

f. Phytoliths and idioblasts. Non-tissue, cellular and extra-cellular plant structures besides starch.

Starch grains under $10 \mu \mathrm{m}$ in maximum dimension were discounted as they were ubiquitous and their association with artefact use was questionable. These grains were therefore considered to be environmental contaminants.

The occurrence of each of these categories on the artefact surfaces was considered with respect to raw materials and through time. The results showed no significant change or variation throughout the assemblage. Similarly any correlation between individual residue elements was tested using Gutman's Lambda co-efficient of predictability. This test would show if certain residue elements, for example fibres and resins, regularly occurred together on artefacts. No significant correlations between residue types were demonstrated.

These results, firstly, indicate a remarkable consistency in the tasks performed at this site over time. Secondly, the results imply only a restricted range of tasks were performed during the period.

\section{Task Identification}

The kinds of residues present on the artefacts found at Roof Fall Cave can give an idea of the materials being worked or processed. The fact that no animal residues were found and that the occurrence of indicators of tuber or bulb processing (e.g. large starch grains, raphides and/or parichymal tissue) were infrequent, makes it unlikely that these artefacts were being used for food processing. In addition, the high amounts of resins, woody tissue and fibres is indicative of woodworking, manufacture and repair tasks. These findings are consistent with ethnographic studies which indicate that present day use of rockshelters is limited to short-term hunting camps, refuges from inclement weather or for occasional ceremonial purposes. Rockshelters are, by and large, not long-term occupation sites where food is prepared or consumed in any quantity (Walthall 1998).

The fact that many of the resins and other residue elements at Roof Fall Cave possibly derive from Xanthorrhea sp. adds weight to this hypothesis. While Xanthorrhea sp. is recorded ethnographically as being widely used (Bindon 1996; Isaacs 1987), this is usually not as a food source but as a resource for manufacture of artefacts.

\section{Conclusion}

The archaeological sequence at Roof Fall Cave represents the oldest evidence for human occupation in Cania Gorge. The low representation of cultural material from deposits dated to before the midHolocene suggests that during this period the site was occupied only ephemerally with low intensity site use and possibly long occupation hiatuses. Deposition of both cultural material and sediment increase after c. $8,500 \mathrm{cal} \mathrm{BP}$. This date and the date obtained for first occupation of the nearby Big Foot Art Site overlap. It may be that it is around this time $(8,500$ cal BP to 7,500 cal BP) that Cania Gorge was first occupied with any regularity or intensity.

Stone artefact and bone discard rates are relatively high and sustained between c.4,000 cal BP and c.550 cal BP after which there is a change in the nature of the assemblage, from deposits dominated by bone and stone artefacts to deposits dominated by large quantities of charcoal. These changes may indicate restructuring in the spatial use of Roof Fall Cave's available floor space after the roof fall occurred. 
Residue analysis suggests that Roof Fall Cave was not used as a long-term occupation site, but rather for transitory occupation possibly for activity-specific purposes. The findings at Roof Fall Cave further contribute to our knowledge of lifeways at Cania Gorge. They verify the pattern so far established at Big Foot Art Site and possibly extend human occupation into the Pleistocene. The results from Roof Fall Cave will also be instructive in determining directions for further studies at other sites in Cania Gorge.

\section{Acknowledgements}

Fieldwork and radiocarbon dates were funded by the National Estate Grants Program and the Aboriginal and Torres Strait Islander Studies Unit at the University of Queensland. Thanks are due to the numerous field assistants who worked on the Roof FallCave excavations including Brit Asmussen, Chris Chicoteau, Malcolm Connolly, Nick Culbert, Linda Tebble, Paul Mícinnes, Kate Quirk, David Reid, Deb Vale and Nathan Woolford. Michael Williams and James Williams visited the site during the excavations. John Richter drew the maps. The Department of Sociology, Anthropology and Archaeology at the University of Queensland provided laboratory facilities for the residue analyses.

\section{References}

Bard, E., M. Arnold, R.G. Fairbanks and B. Hamelin 1993 ${ }^{230} \mathrm{Th}-{ }^{234} \mathrm{U}$ and ${ }^{14} \mathrm{C}$ ages obtained by mass spectrometry on corals. Radiocarbon 35(1):191-199.

Bindon, P. 1996 Useful Bush Plants. Perth: Western Australian Museum.

Briuer, F.I. 1976 New clues to stone tool function: Plant and animal residues. American Antiquity 41(4):478483.

Eales, T. 1998 Stone Soup: A Residue Analysis of Artefacts from Roof Fall Cave, Cania Gorge, Central Queensland. Unpublished B.A. (Hons) thesis, Department of Anthropology and Sociology, University of Queensland, Brisbane.

Isaacs, J. 1987 Bush Food: Aboriginal Food and Herbal Medicine. Sydney: Lansdowne.

Lilley, I., D. Brian, C. Clarkson and S. Ulm 1998 Pleistocene Aboriginal occupation at Cania Gorge, Central Queensland: Preliminary results of fieldwork and implications. Archaeology in Oceania 33(1):28-31.

Lilley, I. and S. Ulm 1995 The Gooreng Gooreng Cultural Heritage Project: Some proposed directions and preliminary results of the archaeological program. Australian Archaeology 41:11-15.

Lilley, I. and S. Ulm this volume The Gooreng Gooreng Cultural Heritage Project: Preliminary results of archaeological research, 1993-1997. Queensland Archaeological Research 11.
Linick, T.W., A. Long, P.E. Damon and C.W. Ferguson 1986 High-precision radiocarbon dating of bristlecone pine from 6554 to 5350 BC. Radiocarbon 28(2B):943953.

Loy, T.H. 1983 Prehistoric blood residues: Detection on tool surfaces and identification of species of origin. Science 220:1269-1271.

Loy, T.H. 1993 The artefact as site: An example of the biomolecular analysis of organic residues on prehistoric tools. World Archaeology 25(1):44-63.

Loy, T.H. 1994 Methods in the analysis of starch residues on prehistoric stone tools. In J.G. Hather (ed.), Tropical Archaeobotany: Applications and New Developments, pp.86-114. London: Routledge.

Loy, T.H. 1997 Prehistoric Stone Tool Residue Analysis. Departments of Archaeology and Biochemistry, University of Witwatersrand.

Mulvaney, D.J. 1975 The Prehistory of Australia. Rev. ed. Melbourne: Penguin.

Mulvaney, D.J. and E.B. Joyce 1965 Archaeological and geomorphological investigations on Mt. Moffat station, Queensland, Australia. Proceedings of the Prehistoric Society 31:147-212.

Pearson, G.W., B. Becker and F. Qua 1993 High-precision ${ }^{14} \mathrm{C}$ measurement of German and Irish oaks to show the natural ${ }^{14} \mathrm{C}$ variations from 7890 to $5000 \mathrm{BC}$. Radiocarbon 35(1):93-104.

Pearson, G.W. and M. Stuiver 1993 High-precision bidecadal calibration of the radiocarbon time scale 500 2500 BC. Radiocarbon 35(1):25-33.

Shafer, H.J. and R.G. Holloway 1979 Organic residue analysis in determining stone tool function. In B. Hayden (ed.), Lithic Use-Wear Analysis, pp.385-399. New York: Academic Press.

Stuiver, M. and G.W. Pearson 1993 High-precision bidecadal calibration of the radiocarbon time scale, AD 1950-500 BC and 2500-6000 BC. Radiocarbon 35(1): 1-23

Stuiver, M. and P.J. Reimer 1993 Extended ${ }^{14} \mathrm{C}$ data base and revised CALIB $3.0{ }^{14} \mathrm{C}$ age calibration program. Radiocarbon 35(1):215-230.

Walsh, G.L. 1984 Managing the Archaeological Sites of the Sandstone Belt. Rockhampton: Central Queensland Aboriginal Corporation for Cultural Activities and the Queensland National Parks and Wildlife Service.

Walthall, J.A. 1998 Rockshelters and hunter-gatherer adaptation to the Pleistocene/Holocene transition. American Antiquity 63(2):223-238.

Westcott, C. 1997 A Technological Analysis of the Stone Assemblage from Big Foot Art Site, Cania Gorge. Unpublished B.A. (Hons) thesis, Department of Anthropology and Sociology, University of Queensland, Brisbane.

Westcott, C., I. Lilley, S. Ulm, C. Clarkson and D. Brian this volume Big Foot Art Site, Cania Gorge: Site report. Queensland Archaeological Research 11. 
Appendix A. Roof Fall Cave, Square A, Excavation Data and Dominant Materials.

\begin{tabular}{|c|c|c|c|c|c|c|c|c|c|c|}
\hline $\mathbf{X U}$ & $\begin{array}{c}\text { Total } \\
\text { Weight } \\
\text { (kg) }\end{array}$ & $\begin{array}{c}\text { Artefactual } \\
\text { Stone } \\
(\mathrm{g})\end{array}$ & $\begin{array}{c}\text { Non-Artefactual } \\
\text { Stone } \\
\text { (g) }\end{array}$ & $\begin{array}{c}\text { Charcoal } \\
\text { (g) }\end{array}$ & $\begin{array}{c}\text { Bone } \\
(\mathrm{g})\end{array}$ & $\begin{array}{l}\text { Organic } \\
\text { Material } \\
\quad(g)\end{array}$ & $\begin{array}{c}\text { Insect } \\
\text { Remains } \\
\text { (g) }\end{array}$ & $\begin{array}{c}\text { Shell } \\
\text { (g) }\end{array}$ & $\begin{array}{c}\text { Ochre } \\
\text { (g) }\end{array}$ & $\begin{array}{c}\text { Earth } \\
\text { Nodules } \\
\text { (g) }\end{array}$ \\
\hline 1 & 3.25 & 5.5 & 190.0 & 80.7 & 5.3 & 96.2 & 1.3 & 1.0 & 0 & 0 \\
\hline 2 & 4.5 & 0.1 & 484.7 & 77.4 & 6.2 & 35.3 & 2.6 & 1.1 & 0.9 & 0.5 \\
\hline 3 & 5.75 & 0.5 & 357.4 & 69.2 & 4.2 & 37.4 & 1.9 & 1.5 & 0.1 & 0.4 \\
\hline 4 & 7.25 & $<0.1$ & 312.9 & 145.2 & 8.9 & 31.1 & 0.5 & 2.2 & 0 & 0 \\
\hline 5 & 5.5 & $<0.1$ & 170.7 & 112.0 & 10.4 & 10.8 & 0.6 & 3.0 & 0.1 & 0.4 \\
\hline 6 & 4.75 & 0.8 & 104.3 & 61.5 & 10.4 & 5.1 & 0.2 & 3.1 & 0 & 1.8 \\
\hline 7 & 3.5 & $<0.1$ & 101.1 & 36.4 & 7.6 & 4.5 & 0.2 & 4.7 & 0 & 13.4 \\
\hline $7 a$ & 0.8 & 0.1 & 28.6 & 9.7 & 1.0 & 0.8 & 0.1 & 0.6 & 0.3 & 0.3 \\
\hline 8 & 5.2 & 0.4 & 141.8 & 32.5 & 5.8 & 2.6 & 0.4 & 4.9 & 0.4 & 5.6 \\
\hline 9 & 5.75 & 0.2 & 159.4 & 16.2 & 7.9 & 1.1 & 0.5 & 7.5 & 0.5 & 11.2 \\
\hline 10 & 5.25 & 3.2 & 193.8 & 7.3 & 5.6 & 0.3 & 0.2 & 6.9 & 0 & 8.4 \\
\hline $10 \mathrm{a}$ & 0.1 & 0 & 0 & 0 & 0 & 0 & 0 & 0 & 0 & 0 \\
\hline $10 \mathrm{~b}$ & 1.0 & 31.8 & 48.9 & 1.7 & 6.1 & 1.3 & 0.1 & 0.3 & 0 & 1.8 \\
\hline 11 & 5.25 & 3.5 & 172.6 & 8.3 & 12.0 & 0.3 & 0.2 & 7.0 & 0 & 3.6 \\
\hline $11 \mathrm{a}$ & 2.0 & 6.1 & 100.7 & 15.3 & 9.6 & 2.2 & 0.1 & 0.5 & 0 & 0.8 \\
\hline $11 \mathrm{~b}$ & 3.0 & 9.5 & 108.6 & 3.7 & 24.7 & 1.2 & 0.1 & 2.1 & 0.3 & 2.8 \\
\hline 12 & 6.0 & 21.5 & 211.5 & 3.7 & 48.2 & 0.4 & 0.1 & 13.9 & 0.7 & 14.8 \\
\hline 13 & 2.5 & 21.1 & 74.6 & 0.7 & 29.7 & 0.3 & 0.1 & 5.0 & 0.3 & 10.4 \\
\hline 14 & 2.25 & 13.9 & 125.6 & 2.8 & 43.3 & 1.5 & 0.1 & 1.8 & 3.0 & 4.8 \\
\hline 15 & 5.0 & 10.8 & 151.3 & 1.2 & 54.6 & 1.1 & 0.1 & 6.6 & 0 & 14.8 \\
\hline 16 & 2.0 & 18.9 & 77.4 & 2.2 & 22.5 & 1.3 & 0.1 & 2.8 & 0 & 0.2 \\
\hline 17 & 3.3 & 12.6 & 148.7 & 1.7 & 33.8 & 2.3 & 0 & 6.6 & 0.4 & 0.3 \\
\hline 18 & 1.6 & 6.1 & 63.9 & 1.3 & 20.2 & 0.8 & 0.1 & 1.8 & 0 & 0.2 \\
\hline 19 & 5.75 & 28.1 & 203.7 & 7.2 & 54.5 & 3.9 & 0.1 & 6.4 & 0.6 & 0.8 \\
\hline 20 & 5.3 & 21.4 & 256.0 & 9.4 & 29.8 & 1.6 & 0.1 & 1.5 & 0.7 & 0.7 \\
\hline 21 & 6.0 & 730.7 & 229.2 & 6.0 & 19.2 & 1.1 & $>0.1$ & 0.7 & 0.3 & 0.3 \\
\hline 22 & 7.3 & 5.2 & 378.8 & 11.7 & 26.6 & 1.1 & $>0.1$ & 0.3 & 0.4 & 0.3 \\
\hline 23 & 6.0 & 1.2 & 398.8 & 11.4 & 11.0 & 2.5 & 0 & 0.1 & 0.5 & 0.3 \\
\hline 24 & 7.0 & 9.5 & 305 & 11.9 & 8.2 & 0.7 & 0.1 & $>0.1$ & 2.6 & 0.7 \\
\hline 25 & 7.0 & 3.8 & 266.7 & 7.4 & 3.3 & 0.6 & 0.1 & $>0.1$ & 3.0 & 0.5 \\
\hline 26 & 7.0 & 41.8 & 243.6 & 5.1 & 2.4 & 1.5 & $>0.1$ & $>0.1$ & 2.6 & 0.1 \\
\hline 27 & 7.0 & 0.6 & 303.7 & $>0.1$ & 2.0 & 0.4 & 0 & 0 & 6.6 & 0.6 \\
\hline
\end{tabular}


Appendix A. Roof Fall Cave, Square A, Excavation Data and Dominant Materials (continued).

\begin{tabular}{|c|c|c|c|c|c|c|c|c|c|c|}
\hline XU & $\begin{array}{c}\text { Total } \\
\text { Weight } \\
(\mathbf{k g})\end{array}$ & $\begin{array}{c}\text { Artefactual } \\
\text { Stone } \\
(\mathbf{g})\end{array}$ & $\begin{array}{c}\text { Non-Artefactual } \\
\text { Stone } \\
(\mathbf{g})\end{array}$ & $\begin{array}{c}\text { Charcoal } \\
(\mathrm{g})\end{array}$ & $\begin{array}{c}\text { Bone } \\
(\mathrm{g})\end{array}$ & $\begin{array}{c}\text { Organic } \\
\text { Material } \\
(\mathbf{g})\end{array}$ & $\begin{array}{c}\text { Insect } \\
\text { Remains } \\
(\mathbf{g})\end{array}$ & $\begin{array}{c}\text { Shell } \\
(\mathrm{g})\end{array}$ & $\begin{array}{c}\text { Ochre } \\
(\mathrm{g})\end{array}$ & $\begin{array}{c}\text { Earth } \\
\text { Nodules } \\
(\mathbf{g})\end{array}$ \\
\hline 28 & 8.2 & 1.1 & 359.2 & 2.4 & 1.3 & 1.4 & $>0.1$ & 0.1 & 4.5 & 0.5 \\
\hline 29 & 7.25 & 1.3 & 353.5 & 2.8 & 1.0 & 0.2 & 0 & $>0.1$ & 2.6 & 0.3 \\
\hline 30 & 7.25 & 3.8 & 274.7 & 2.3 & 0.1 & 0.3 & $>0.1$ & 0 & 0.7 & 0.3 \\
\hline 31 & 6.75 & 0.5 & 302.9 & 1.4 & 0.2 & 0.8 & $>0.1$ & 0 & 1.5 & 0.4 \\
\hline 32 & 7.75 & $>0.1$ & 593.8 & 0.7 & 0 & 1.1 & 0 & 0 & 1.7 & 0 \\
\hline 33 & 6.5 & $>0.1$ & 343.9 & 0.5 & 0 & 1.6 & 0 & 0 & 6.1 & 0 \\
\hline 34 & 7.5 & 0 & 650.2 & 0.7 & 0 & 0.5 & 0 & 0 & 1.5 & 0.2 \\
\hline 35 & 7.25 & 0 & 682.0 & 2.1 & 0 & 1.3 & 0 & 0 & 8.1 & 0 \\
\hline 36 & 8.5 & 0 & 501.1 & 1.4 & 0.2 & 0.9 & 0 & 0 & 0.5 & 0 \\
\hline 37 & 12.5 & 0 & 1101.7 & 7.2 & 0 & 1.5 & 0 & 0 & 0 \\
\hline 38 & 12.75 & 0 & 910.5 & 5.3 & 0 & 0.8 & $>0.1$ & 0 & 0 \\
\hline
\end{tabular}

